\title{
Executive Pay Inefficiencies In The Financial Sector
}

Haley Barton, Colorado College, USA

Judith A. Laux, Colorado College, USA

\begin{abstract}
This study considers the implications of excessive non-salary-based executive pay on capital structure during the years 2005 through 2007, directly preceding the 2008 stock market crash. The hypothesis proposes that for firms in the financial sector, executives awarded generous compensation packages, compared to salary, implemented a higher use of debt in their firm's capital structure. The study examines data on 40 firms in the financial sector and 40 firms in the manufacturing sector to empirically test for a relationship between executive pay and leverage. Cross-sectional analysis of nine models reveals that compensation is a significant determinant of a firm's total debt-to-total assets ratio for the financial sector, especially with the existence of a one- to two- year lag between the variables, while the manufacturing sector yielded no significant relationship. These findings reveal sources of agency conflicts and behavioral biases within the financial sector during the three years preceding the financial collapse.
\end{abstract}

Keywords: Executive Compensation, Leverage, Agency Theory

\section{INTRODUCTION}

$\mathscr{J}$ he entire world felt the effects of the 2008 stock market crash, which was considered the worst economic meltdown in U.S. history since the 1929 catastrophe. On September 29, 2008, the Dow Jones Industrial Average plummeted 778 points, the largest one-day drop in history, leaving shareholders, businesses, and families in the harsh realities of a recession (Altman and Romero). The financial sector experienced the greatest devastation of any other sector.

Although most financial institutions survived the market's plunge or were fortunate enough to acquire funding from the government bailout, longstanding firms, such as Bear Stearns and Lehman Brothers, did not have enough cash to stay afloat. Before the investment bank's collapse, Bear Stearns' executives boasted some of the largest compensation packages in the industry. From 2002 to 2006, prior Bear Stearns CEO, Jimmy Cayne, received a total compensation package worth $\$ 156$ million, with bonuses representing the most extensive share (Levisohn 2008). Many of these large financial firms offered higher executive pay and levels of debt usage than other firms in the sector, putting into question whether managers of these firms upheld their fiduciary duty to act on behalf of the firm's shareholders.

This study seeks to address whether shareholder wealth maximization was challenged by compensation plans urging executives in the financial sector to over-lever. Excessive compensation packages and risky business practices in the financial industry are analyzed for the three-year period directly preceding the 2008 stock market crash. The hypothesis states that for the years 2005 through 2007, executives in the financial industry with higher non-salary compensation packages took on significantly more debt in their firm's capital structure in comparison to manufacturing executives. This line of research sheds light on agency conflicts between managers and shareholders, behavioral biases of managers, the efficient market hypothesis, the inefficiencies that caused the recent financial crisis, and the rebuilding of the current economy.

The paper first presents an overview of literature related to the topic while explaining some of the key economic theories that provide the foundation for this study. The next section reviews the data set and methodology 
used to examine nine models investigating the relationship between executive pay and leverage. The study uses data on manufacturing firms, as well as financial firms, to provide a comparison of other sectors to the financial industry. Finally, the paper provides an empirical analysis of the nine models and discusses the significance of compensation packages for determining a firm's debt usage.

\section{THEORY \& LITERATURE REVIEW}

In analyzing the many roles top executives play in a firm, one assumes the overall wellbeing of the firm depends on the preservation of the fiduciary duty defined by the agency relationship between managers and shareholders. While shareholder wealth maximization should be the primary goal of executives, conflicts between managers and owners inevitably arise due to the varying interests of these two groups. John \& John (1993) use a two-period model with heterogeneous agents to investigate the actions of managers given incentive contracts designed by the board of directors to maximize shareholder wealth. The empirical findings show that precise alignment of shareholder interest to executive compensation is only optimal for firms using $100 \%$ equity financing. These results reveal the difficulty in upholding agency relationships for firms that implement high degrees of debt financing, illuminating inefficiencies created by incentive-based pay contracts for executives.

Further studies have analyzed whether a greater use of equity-based incentives compared to debt-based incentives help align shareholder and manager interests. Zhang et al. (2008) use regression analysis in their study to test the effects of stock-based incentive options, firm performance, and CEO tenure on earnings manipulation activities of CEOs. The results provide evidence that stock option grants do not aid in aligning manager/shareholder interests and can result in earnings manipulations. Lam and Chng (2006) use an Ordinary Least Squares Regression of cross-sectional data to analyze some of the motivations for using stock option awards, such as value enrichment, tax benefits, risk-taking, signaling, and cash conservation. Their results strongly support the argument that high-risk firms implement stock option grants to encourage high leverage. Although boards of directors have thought that equity-based incentives uphold manager/shareholder relationships, these studies reveal that, when used in excess, this type of award has a negative impact on the alignment of manager and shareholder interests.

With agency theory providing a foundation for the debate over executive compensation plans, literature describing incentive contracts for executives uncovers motives for the crafting of capital structure. While some managers may wish to take on a conservative approach to capital financing to reduce the company's risk, large compensation packages provide an incentive for many executives to increase their firm's leverage in hopes of higher rewards. Berkovitch, Spiegel, and Ronen (2000) use a three-period cross-sectional model tracing managerial financing activity to test for the connection between shareholder/manager interests, capital structure, and compensation for firms that either retain or release their managers. This study finds that executive compensation, leverage, and cash flow positively relate for firms that retain their managers. Harjoto and Mullineaux (2003) investigate the compensation strategies of commercial bank holding companies, finding a strong relationship between incentive compensation and firm performance. Further, the results find that the volatility of returns positively relates to all components of executive compensation. These findings suggest a strong positive correlation between the returns associated with high-risk transactions and executive pay.

The negative effects of excessive managerial pay on shareholder wealth maximization and firm performance evidence market inefficiencies that challenge the efficient market hypothesis. Incentives dictating managers' decisions reveal biases that the field of behavioral finance endorses as inevitable features of the financial world. Bolton, Scheinkman, and Xiong (2006) use a multi-period agency model to examine the effects of executive stock-based compensation on a company's short and long-term price valuation. Allowing investors to have heterogeneous beliefs, the model allows for behavioral biases, permitting deviations in stock prices from their true worth. Because of these price inefficiencies, companies altered CEO compensation plans to provide incentives to achieve short-term price goals, even at the expense of long-term values. Short-term price goals are detrimental to a company's long run success, evidenced by financial institutions such as Bear Stearns who failed to realize the implications of their high risk, high reward transactions.

Economists have begun to look at cognitive explanations of behavioral patterns such as overconfidence, anchoring, overreaction and herding to explain reactions of managers and investors. A 2009 study by Gort examines 
the idea of overconfidence to analyze the debate surrounding active management versus indexing. Of the managers studied, the findings suggest that most adopt an overconfident attitude in their management performance. The majority believe their plan to be above average in outperforming other pension plans (pp. 77-79). Because overconfidence in managerial performance has been evidenced in many studies, the propensity of managers to take on high levels of debt in the capital structure, coupled with pressures from incentive plans, puts many firms in a riskier position than is constructive for maximizing firm performance.

Literature relevant to the current study is timely, widespread, and comprehensive. The surprise of the financial crisis and the malpractice of some of the largest financial institutions left shareholders demanding answers and transparency about executive pay. While the studies mentioned above all provide insight into the analysis of the relationship between executive compensation packages and capital structure, research has not yet examined the implications of compensation packages on leverage for firms in the manufacturing sector compared to firms in the financial sector. Analyzing the results from these sectors will enhance current understanding of the causes of the 2008 stock market crash and put into question the ethical practices of firms involved and the long-run implications of executive compensation strategies.

\section{DATA \& METHODOLOGY}

The current study investigates whether incentive-based compensation plans serve as behavioral biases for top executives, affecting their decision-making process and actions. Because a firm's capital structure has a significant influence on the success or failure of a firm, the hypothesis predicts that executives in the financial sector who receive elevated incentive or performance-based pay take on riskier capital structures to reap these additional rewards. Excessive debt usage may divert executives from upholding shareholder wealth maximization and provide a tendency to work towards short-term goals.

Figures on executive pay and leverage were collected for 40 firms in the financial sector and 40 firms in the manufacturing sector. Using data from the three-year period 2005 through 2007, the study examines firm activity and strategies at the climax of the financial boom. Only large-cap firms with revenues equal to or exceeding $\$ 5$ billion were used to better capture the affects of extreme executive pay, most prominent in large firms with enough capital to support significant compensation packages.

The hypothesis states that, due to the risk-increasing nature of incentive-based pay, executives with a more substantial compensation package compared to salary will implement a higher degree of debt usage in the firm's capital structure. In the basic model,

$(\mathrm{TL} / \mathrm{TA})_{\mathrm{Y}}=\beta_{0}+\beta_{1}(\text { Compensation })_{\mathrm{Y}}-\beta_{2}(\text { Salary })_{\mathrm{Y}}$,

the amount of leverage in a firm's capital structure (dependent variable) relates to Compensation and Salary (independent variables), where $\mathrm{Y=1,2}$, or 3 corresponds to the years 2005, 2006, and 2007, respectively. The dependent variable reflects a firm's total liabilities-to-total assets ratio, or debt ratio, which was calculated from Mergent Online's company financials section. Compensation reflects the total compensation minus salary as listed in the Security and Exchange Commission's (SEC) Summary Compensation Tables for the top three highest-paid executives in each company for a given year. Data were collected on the three highest-paid executives to provide the most accurate representation of the managers in a company who hold the most influence over capital structure. Total Compensation reflects the sum of salary, stock awards, option awards, non-equity incentive plan compensation, change in pension value and nonqualified deferred compensation earnings, and all other compensation. Similarly, Salary reflects the sum of the salary of the three highest paid executives of a company for each year. Because this study examines the effects of Salary and Compensation (measured in thousands and millions of dollars) on the debt ratio (measured as a fraction), the data were standardized to give each variable equal weight (Wooldridge 2009, p. 3).

The model predicts that Compensation will positively influence the debt ratio, while Salary will have a negative impact on the debt ratio. Cross-sectional analysis of three models analyzing the data on the financial sector for 2005, 2006, and 2007 are compared to three models analyzing data on the manufacturing sector for those same 
years. Three additional models test for lag relationships between the independent and dependent variables. The presence of a lag relationship is probable, because if an executive is told he or she will receive a significant bonus at the end of the year if a certain performance standard is reached, even if a riskier capital structure is proposed immediately, the change may not take place right away. For example, an executive that decides to raise cash by distributing bonds may have to wait a significant period of time to float the bond issue. The next section provides an empirical analysis of the nine models and discusses model reliability tests.

\section{RESULTS \& ANALYSIS}

The standardized data were analyzed using Ordinary Least Squares (OLS) to produce estimators for the nine linear regression models.

\section{Analysis of the Financial Sector}

The OLS regression results for the financial sector yielded the following equations:

$(\text { TL/TA })_{1}=0.313061(\text { Compensation })_{1}-0.153505$ (Salary) ${ }_{1}$, $(\mathrm{TL} / \mathrm{TA})_{2}=0.317282(\text { Compensation })_{2}-0.038811$ (Salary $)_{2}$,

$$
(\mathrm{TL} / \mathrm{TA})_{3}=0.173618(\text { Compensation })_{3}-0.261934 \text { (Salary) }_{3} \text {. }
$$

The contrasting signs of the beta coefficients of the independent variables support the hypothesis that Compensation will positively affect the debt ratio while Salary will negatively affect the debt ratio. The p-statistics for the t-test reveal that Compensation is significant at the $1 \%$ level for all three models, demonstrating that Compensation is a highly significant determinant of the debt ratio. Further, the p-values for the F-test reveal that Compensation and Salary are jointly significant at the 5\% level for 2005 and the $1 \%$ level for 2006 and 2007. Although salary was found to be insignificant, this result is logical because most firms issue a base salary independent of what level of compensation the firm offers its executives, making the variation in the data for salary relatively small.

The R-squared values, $20.97 \%, 25.79 \%$, and $25.04 \%$, for the years 2005 , 2006, and 2007, respectively, reveal that a relatively small portion of the variation in the debt ratio is explained by compensation and salary. However, narrowing in on the relationship between executive pay and financial leverage will naturally produce low $\mathrm{R}$-squared values, because other factors are not taken into account. Focusing on one of these factors allows the model to test whether excessive compensation packages provide an incentive for executives to use more leverage in financing activities, independent of other influences.

Tests of the Gauss-Markov assumptions were then conducted to determine the reliability of the model and any bias in the OLS estimators (Wooldridge 2009). The White Test for heteroskedasticity revealed that the variance in the standard error terms is consistent for each of the models, reflecting that the homoskedasticity assumption is upheld. Further, the Jarque-Bera Test for normality of the error terms and the test for multicollinearity upheld the model's dependability. The high statistical significance of Compensation as a determinant of leverage coupled with the support of the Gauss-Markov assumptions provides strong evidence supporting the hypothesis.

\section{Analysis of the Manufacturing Sector}

The regression results from the standardized data set for the manufacturing sector yield the following OLS regression equations,

$2005 \quad(\mathrm{TL} / \mathrm{TA})_{1}=-0.212522(\text { Compensation })_{1}+0.218392$ (Salary) ${ }_{1}$

$2006 \quad(\mathrm{TL} / \mathrm{TA})_{2}=-0.228096(\text { Compensation })_{2}+0.245767{\text { (Salary })_{2}}_{2}$

$2007 \quad(\mathrm{TL} / \mathrm{TA})_{3}=-0.226588(\text { Compensation })_{3}+0.248599$ (Salary) $)_{3}$.

The signs of the beta coefficients for the manufacturing sector reveal opposite results from those for the financial sector analysis. These models suggest that Compensation negatively affects leverage, while Salary 
positively influences leverage. The t-test reveals that although Salary is statistically significant at the 5\% level for each of the models, Compensation is not a statistically significant indicator of the debt ratio for any of the three years. These results provide evidence that the positive relationship between Compensation and leverage is specific to the financial sector, and that within the manufacturing sector, a higher Salary-based compensation positively influences the amount of debt financing of a firm, reflecting an opposing relationship between the two sectors.

The R-squared values, $13.56 \%$ for $2005,12.85 \%$ for 2006 , and $10.64 \%$ for 2007 suggest a weaker relationship between the independent and dependent variables for the manufacturing sector, revealing that executive pay has a higher influence over capital structure within financial institutions compared to manufacturing firms. Although the models upheld homoskedasticity and normality of the error terms, multicollinearity of the independent variables was present in 2006, suggesting that Salary and Compensation were too highly correlated to simultaneously represent reliable predictors of the debt ratio for all three years. Because the Gauss-Markov assumptions did not hold for all three models, no conclusions could be drawn about executive pay as a predictor of leverage for manufacturing firms.

These insignificant results for the manufacturing sector provide support for the hypothesis that the excessive compensation packages influenced executives in the financial sector to implement increased debt usage, while this relationship was not present in other sectors. This result was evidenced by the increased devastation the financial sector experienced from the 2008 stock market crash compared to other sectors.

\section{Analysis of Lag Models within the Financial Sector}

Three models tested for lag relationships between executive pay and debt usage in the financial sector. The models regressed Compensation and Salary from 2006 on the debt ratio from 2007, Compensation and Salary from 2005 on the debt ratio from 2006, and then a two-year lag model regressing Compensation and Salary from 2005 on debt from 2007. The models will be referred to as Lag2007, Lag2006, and TwoLag2007, respectively. The OLS regression equations are:

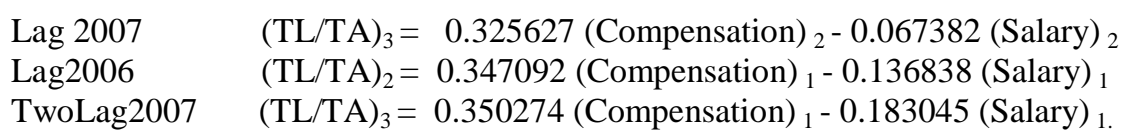

Consistent with the hypothesis and the original three models for the financial sector, Compensation positively relates to the debt ratio and Salary negatively relates to the debt ratio. While Salary remains an insignificant determinant of the debt ratio, Compensation proved even more significant with a one- or two-year lag. The p-stats for the t-test reveal that Compensation is highly significant at the $1 \%$ level for all three models. Further, the F-test provides evidence that Compensation and Salary are jointly significant at the $1 \%$ level for the three models. The R-squared values, 27.95\% for Lag2007, 23.36\% for Lag2006, and 25.49\% for TwoLag2007 suggest a stronger relationship with the presence of a one- or two- year lag than the original financial sector models indicated. All three models possess homoskedasticity, normality of the error terms, and pass the test for multicollinearity of the independent variables, suggesting that the Gauss-Markov assumptions hold and the models are robust.

This study reveals empirical evidence supporting the hypothesis that a relationship exists between top executive pay and leverage in the financial sector for the three-year period 2005 through 2007, especially when a one- to two- year lag is present. The insignificant results from the manufacturing sector provide evidence that this relationship is specific to firms in the financial sector, providing insight into the effects of excessive compensation packages in the financial industry.

\section{LIMITATIONS AND EXTENSIONS}

While the results produced significant figures supporting the hypothesis, this study recognizes restrictions to the analysis of this topic. Time constraints and hand calculations involved in the data collection process limited the data set to 40 firms in the financial sector and 40 firms in the manufacturing sector. Despite the small sample size, quantity was sacrificed so that figures collected on salary and compensation could reflect a combination of the 
top three executives in each firm. While other studies boast larger data sets, most only examine the effects of CEO compensation plans on capital structure. This study recognizes that a firm's CEO may not carry the most influence over capital structure changes, proposing that the package offered to the three highest-paid executives provides a better representation of the executive impact on debt and equity changes.

Another limitation stems from the inability of the study to test for lag relationships greater than two years. Only the TwoLag2007 model was able to test for a two-year lag. Although the study recognizes that changes in capital structure may take time to realize, this period may be greater than two years in many cases. While the current study was limited to a three-year period, significant t-stats and F-stats indicated that Compensation was significant for determining the debt ratio within the financial sector, the primary goal of this thesis.

The results allow for a better understanding of the origins of risky business transactions among financial institutions, although other factors contributing to leverage usage must be accounted for as well. Other studies have examined the contributions of executive age, length of employment within a company, the number of independent directors on a firm's board of directors, production costs, executive pay-performance ratio, a firm's age, and financial distress measures, to mention a few. Adding more independent variables to the model would likely produce a higher R-squared value and allow for the analysis of additional factors that influence financial leverage. Further, ${ }^{1}$ a mutual relationship may exist between the independent and dependent variables in which changes in leverage may also influence the type of compensation packages executives receive. It is also possible that in many cases a cause-effect relationship between executive compensation and capital structure does not exist at all; rather, other influences play into the amount of risk a firm takes on in its capital structure. Factors relative to the period preceding the 2008 financial crisis include the effects of Fannie Mae and Freddie Mac on the mortgage industry. Their propensity to buy riskier securities to stimulate the industry and produce more capital for both home buyers and financial firms may have led these institutions to increase their financial leverage due to the decrease in business risk supported by these government-sponsored enterprises.

A few extensions could be made from this study to be researched in the future. While the study only analyzes data on large-cap firms, an interesting addition would be to examine whether a relationship between executive pay and leverage within the financial sector exists for small- and mid-cap firms as well. A comparison of capital structure industry averages would also give insight into whether a relationship exists between firm size and debt and equity mix and which sectors diverge from or converge to industry averages. Further, separating Compensation into debt-based incentives and equity-based incentives exhibits another interesting extension from the current study. While firms often provide equity-based incentives in managerial compensation packages to help align executive and shareholder interests, excessive amounts of stock options may also provide incentives for managers to elevate share prices in the short run at the expense of long-term goals. This extension would shed light on the actual implications of debt versus equity incentives on share prices and long-term firm performance.

\section{CONCLUSION}

This study addresses the risky business activities invoked by top executives in the financial sector leading up to the 2008 financial crisis. Economists deemed the recent stock market crash as the worst financial catastrophe in the country's history since the 1929 stock market collapse. Executives of financial institutions gambled with leverage, using high levels of borrowed money to finance investment activity. These risky transactions largely contributed to the credit crisis and the collapse of the stock market. This thesis examined the effects of executive compensation plans, one of the primary incentives urging executives in the financial sector to take on elevated levels of debt. An empirical test examined the accuracy of the hypothesis, stating that within the financial sector, nonsalary compensation positively affects a firm's debt ratio, while salary negatively affects the debt ratio. These findings provide evidence supporting behavioral biases among managers and the presence of market inefficiencies, opposing the Efficient Market Hypothesis. The results also raise issues relating to agency relationships between managers and shareholders, putting into question executives' duty to maximize shareholder wealth. Examining executive pay is crucial to the rebuilding of a financial industry that is based on integrity and sound business practices and to reestablishing trust between managers and shareholders.

\footnotetext{
${ }^{1}$ The authors wish to thank John Howe, Missouri Bankers Chair and Professor of Finance at the University of Missouri, for the insights offered in the remainder of this paragraph.
} 


\section{AUTHOR INFORMATION}

Haley Barton is a 2010 Mathematical Economics graduate from Colorado College whose senior thesis provided the basis for this work.

Judy Laux is a Gerald L. Schlessman Professor of Economics and Business at Colorado College, teaching and researching in the areas of accounting and finance.

\section{REFERENCES}

1. Altman, Alex and Frances Romero. "Top 10 Dow Jones Drops." TIME.http://www.time.com/time/specials/packages/article/0,28804,1845523 1845619,00.html.

2. Berkovitch, Elazar, Yossef Spiegel, and Israel Ronen. "Managerial Compensation and Capital Structure." Journal of Economics and Management Strategy 9, no. 4 (Winter 2000): 549-84.

3. Bolton, Patrick, Jos Scheinkman, and Wei Xiong. "Executive Compensation and Short- Termist Behaviour in Speculative Markets.” Review of Economic Studies 73, no. 3 (July 2006): 577-610.

4. Gort, Christoph. "Overconfidence and Active Management: An Empirical Study Across Swiss Pension Plans." Journal of Behavioral Finance 10, no. 2 (2009): 77-79.

5. Harjoto, Maretno and Donald J. Mullineaux. "CEO Compensation and the Transformation of Banking." Journal of Financial Research 26, no. 3 (Fall 2003): 341-54.

6. John, Teresa A. and Kose John. "Top-Management Compensation and Capital Structure." The Journal of Finance 48, no. 3 (July 1993): 949-73.

7. Lam, Swee-Sum and Bey-Fen Chng. "Do Executive Stock Option Grants Have Value Implications for Firm Performance?” Review of Quantitative Finance and Accounting 26, no. 3 (May 2006): 249-74.

8. Levisohn, Ben. "Bear Sterns Big Shots Reaped Big Paydays. ” MSNBC. http://www.msnbc.msn. com /id/ 23711023/ (accessed February 28, 2010).

9. Wooldridge, Jeffery M. Introductory Econometrics: A Modern Approach. 4th ed. Ohio: South-Western Cengage Learning, 2009.

10. Zhang, Xiaomeng, Kathryn M. Bartol, Ken G. Smith, Michael D. Pfarrer, and Dmitry M. Khanin. “CEOs on the Edge: Earnings Manipulation and Stock-Based Incentive Misalignment." Academy of Management Journal 51, no. 2 (April 2008): 241-58. 
NOTES 